\title{
Moore, Pound, Syllabics, and History
}

\author{
Fiona Green
}

\section{$\mathrm{I}_{\mathrm{n}}$}

n Ezra Pound's well-known account of the ideogrammic method, five words stand for the "abbreviated pictures" that register a thought signified in English by the abstraction "red":

\section{ROSE CHERRY}

\section{IRON RUST FLAMINGO}

"A language written in this way," says Pound, in pictures of things or groups of things sharing a common quality, "simply . . . couldn't help being and staying poetic in a way that a column of English type might very well not stay poetic" $(1934,22)$. Pound first published Ernest Fenollosa's "Chinese Written Character as a Medium for Poetry" in 1919 and returned to it in his $A B C$ of Reading in 1934. In that rendering, quoted here, page space and capitals restore some of the thingness that's lost in the translation from ideogram to English type. Yet to dwell on the material particulars of the English words - to notice their letterswould be to miss Pound's point, which is the paradoxical concreteness and transparency of Chinese "words," whose readers do not so much read as "look" and immediately "know" when they see the pictogram FLAMINGO. In 1916, a flamingo had drifted briefly into Marianne Moore's "Critics and Connoisseurs": "I remember a swan under the willows in Oxford," she writes, "with flamingo-colored, maple- / leaflike feet" (BMM 77). ${ }^{1}$ The flamingo is there primarily, as it is in Fenollosa and Pound, to lend color, yet its stubborn birdness along with the maple leaf also makes of Moore's swan an ungainly avian-botanical composite. Most importantly for the purposes of this article, "Critics and Connoisseurs" prompts us to see the syllabic stuff of which "flamingo" itself is composed. In a poem that begins by listing "Certain Ming / products, imperial floor coverings of coach- / wheel yellow," "flamingo" refers back, by the 
accident of its middle syllable, to the collectibles assembled in that first stanza, and these, along with the "plate" at its end and the swan under the willows, combine to produce a version of willow pattern. Whereas Pound mystifies the Chinese character and the poetry it inspires by insisting on its immediacy, Moore's verse, in making us notice its syllables, brings accidents of transmission into the service of poetic thought, in this case, as it happens, about ersatz reproductions of the Orient.

"The Chinese 'word' or ideogram for red is based on something everyone KNOWS," wrote Pound, and added, in parentheses, "If ideogram had developed in England, the writers would possibly have substituted the front side of a robin" $(1934,22)$. A year later, Marianne Moore composed "Virginia Britannia," a poem about the colonization of North America that listed "the redbird" among its native fauna. This article is about a preoccupation with nation-building narratives that Moore and Pound shared in the 1930s. Its focus is The Pangolin and Other Verse (1936), the book in which "Virginia Britannia" appeared, and an exchange of letters between the two poets that took place in 1935, partway through Moore's work on that book. My concern is the intricate relationship for each poet between the composition of poetry and the fabric of history. The central claim of this article is that whereas Pound detects the rhythmic coherence of a robust economy beneath the surface differences of documented history, Moore's attention to the syllabic material of the prose she read trained her attention on the contingent aspects of historical narrative, and on the accidental likenesses whereby nations make themselves up.

Moore's experiments with syllabics in the 1910s may have been prompted in part by the vogue among the imagist poets for syllabically controlled Japanese forms such as the haiku. When she returned to syllabic stanzas in the 1930s she had also developed a "hybrid method of composition" that had its fullest expression in long free-verse poems such as "An Octopus" and "Marriage," poems made up almost entirely of quotations from prose sources. ${ }^{2}$ As I have suggested briefly elsewhere, when syllabics and quotation come together in the densely worked stanzas of the 1930s, Moore's method of composition is inextricably bound up with a reading practice habitually distracted by the material components of prose (see Green 2015, 38-40). The thought developed in this article is that the practical work of counting syllables makes Moore into a particularly fidgety reader. If you settle to the kind of work that she must have done by taking any syllabic poem ("The Fish," "The Steeple-Jack," "The Pangolin") and checking its line lengths, and then, 
Moore, Pound, Syllabics, and History

after five or ten minutes, stop counting syllables and read some prose-a newspaper, a cereal packet, the minutes of a meeting (the less "poetic" the better) - something strange will happen. The surface of the writing will be animated with likenesses, with the kinds of accidental pattern that lurk in the most prosaic of texts waiting for a distractible reader like Moore to find them. Take, for example, this passage from the journal Natural History:

Though there are many animals in the world known as anteater, the pangolins are apparently the only creatures which specialize in eating true ants, the other anteaters preferring the less dangerous antlike termites. But, in Africa at least, the pangolins fear no ant, sometimes going deliberately after army ants, insects which, though small, are formidable for their aggressiveness and great numbers. The formic acid carried into the skin by an ant bite is so unpleasant that we may well imagine the taste for ants must have been a long time in acquisition. (Hatt 1934, 725, 728)

Notice-this is what you would notice if you had been counting syllables — all the ans and ants, the stammer in "an ant bite," the ant carried in "unpleasant," and the one heard if not seen in "apparently"; spot the "eat" at the heart of "creatures" and "great," the "gre" common to "great" and "aggressiveness," and the syllable shared by "formidable" and "formic." At the same time, something happens to sense: once occupied at the prose surface collecting and connecting ans and ants, eats and forms, the reader attentive to syllables will almost certainly lose track of what the prose says. Of course this is to overread the natural history passage, but my purpose in thus misreading it is to illustrate that for Marianne Moore two aspects of composition, counting syllables and reading prose, are inextricably conjoined, and that the product of their marriage is not just verse that sounds prosy because the ear accustomed to accentual rhythms is deaf to units measured by syllable count, but prose whose constituents come to its surface and, in forming a diversion from what the writing says, participate in the revived materiality that animates poetic language.

"The pangolin," writes Robert Hatt, assistant curator in the department of mammals at the American Museum of Natural History, "has indeed a leafy appearance that has caused visitors to my office, when seeing a curled up skin fresh from the field, to enquire whether the object was an artichoke or a pine cone" $(1934,725)$. Under Moore's curation, this creature, easily mistaken for other things, converts readily into a poem whose syllabic medium tempts us to construe accidental 
likeness as motivated connection or natural kinship. When we read in the poem's first stanza about "this near artichoke," the sense of the verse- that a pangolin looks a bit like an artichoke and a bit like a pine cone-gets sidetracked by the proximity of "artichoke" to "artist" ( $A$-Q 27), kin in sharing a syllable. "The Pangolin" thus begins as a poem about mistaken identity, its first stanza posing a question about lineage ("[The pangolin] is Leonardo's indubitable son?"). I will go on to suggest that the sources of this poem also prompted Moore's thinking about lineage and likeness in the context of American history, a concern most fully articulated in "Virginia Britannia," the late addition to The Pangolin and Other Verse that gave that book its eventual starting point.

The source material for "The Pangolin" was not confined to zoology. Moore's published notes credit one line- "the sailboat was the first machine"- to "Power by F. L. Morse." Power is a small pamphlet about engineering and the part that technology has played in the progress of nations. "From the beginning of history," writes Morse, "the growth or degree of civilization of a race or nation can be determined by their development and application of power transmission" (1923, 2). Moore acknowledges her borrowing from this early passage: "Under the old kingdom of Egypt . . . there was only one power, with the exception of muscular strength, which was plied to anything that might be considered a machine, and the machine was the sailboat" (3), though she does not identify the forebear of her "artist- / engineer, ... Leonardo" ( $A$-Q 27) in Morse's "Leonardo da Vinci who was not only one of the world's greatest artists but the greatest engineer and inventor of this period" $(1923,21)$. Morse's tale of technological inventiveness advances swiftly to the machineries that drive the modern nation state, taking in, for example, the furnaces in which arms for the War of Independence were manufactured. After thirty-nine pages and roughly six thousand years of technological ingenuity, this is where Power ends up: "All of these epochmaking inventions in prime movers and their applications to machines, created revolutionary demands in power transmission. In one way or another these involved the transmission of great power at a controlled and often high speed, in a small space, and without noise. This has led to combinations of steel link belts and sprockets. The Rocker Joint of these so-called silent chains was invented by Morse in 1901" (39). This pamphlet tells the most conspicuously end-directed of stories. A transcript of Frank Lincoln Morse's address to the 16th annual mining convention 
in Milwaukee, and published by his own Morse Chain Company, it's a history of power designed to end with his invention, in 1901, of the silent, frictionless, rocker-jointed Morse chain. The Egyptian sailboat, Leonardo's linked sprocket chains (figure 1), the first ironworks in colonial Virginia - all of these were but steps on the road to the rocker joint. Marianne Moore makes something of these so-called silent chains in her pangolin poem:

so. Pangolins are

not aggressive animals; between

dusk and day, they have the not un-

chainlike machine-

like form and

frictionless creep of a thing

made graceful by adversities (A-Q 29)

Among the things that "The Pangolin" carries in its makeup, then, is a whiggish history, a narrative of power that has at its beginning and its end a silent mechanism — a sailboat and a frictionless chain-strange replicas of the pangolin, an armored animal, says Moore, "made / for moving quietly," and of the silent formal machinery whereby that creature is articulated in the verse.

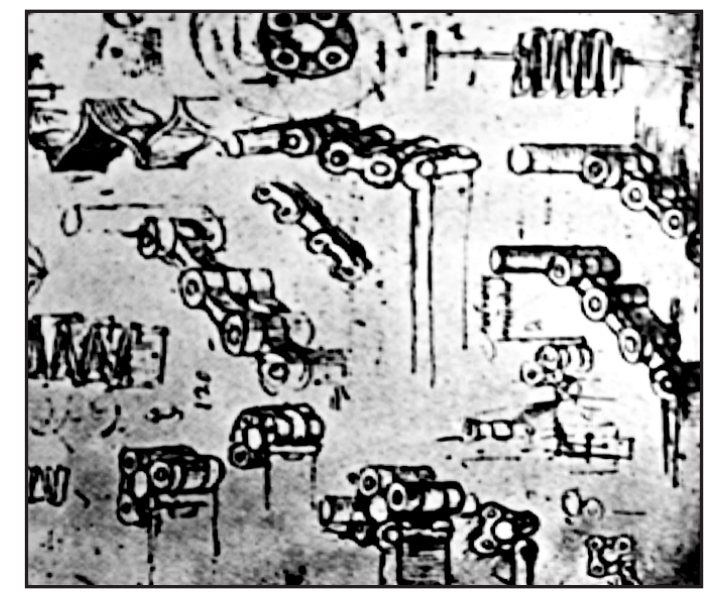

Figure 1. Leonardo da Vinci “Codice Atlantico” (1484). In Morse 1923, 22.

This reading of "The Pangolin" makes explicit two kinds of poetic thinking. One of them, distracted by the medium of transmission, is captivated by verbal pattern and coincidence and goes skittering across the written surface in the kind of lateral movement that's activated by Moore's syllabics. Set against that diverted attention is a more strictly linear kind 
of thought, in the case of the pamphlet about power, a narrative that is resolutely end-directed - the kind of history whose quiet machinery marshals all contingencies into the service of its advancing plot. In the 1930s, when retellings of US history in print and in the curated landscape became pressing cultural concerns, and personal preoccupations of Marianne Moore's, these two modes of attention competed in her reading and writing about the origins and history of her own nation.

Moore published "The Pangolin" as the last poem in The Pangolin and Other Verse (1936), where it followed four poems grouped under the heading "The Old Dominion." The book opens with "Virginia Britannia," the last of the Old Dominion poems to be written and, as Heather White shows in meticulous detail, the poem that "turn[ed] what might have been a book of unrelated animiles into a more ambitious and pointed statement of Moore's thinking about the intersection of her roles as poet and American citizen" ( $A$-Q xix). A number of suggestions have been made about thematic continuities between the Old Dominion poems and "The Pangolin." Moore's "armored animal," for example, "who endures / exhausting solitary / trips through unfamiliar ground" (27), might be a match for her "able / sting-ray-hampered pioneer" Captain John Smith (14). ${ }^{3}$ My reading of the source material indicates a still closer affinity between these two poems that goes back to a common point of origin. Among the primary sources for "The Pangolin" was Richard Lydekker's entry under "MANIS" in the Royal Natural History. Like Robert Hatt, Lydekker comments on the pangolin's resemblance to "an animated spruce-fir cone furnished with a head and legs" (1894-95, 3:226), thereby supplying Moore with the ans that proliferate in the first stanza of her poem. She probably also noticed that pangolins belong to the Old World: "As already mentioned, the relationship of the [African and Asian] pangolins to the typical New World Edentates is remote; and it may even be questioned whether the group is rightly included in the same order. Their internal anatomy is of a different type; and the joints of the backbone lack the additional articular processes characterising most of the American Edentates." Moore was well aware that an edentate is an animal lacking teeth, but her restless eye was surely caught by the happy accidents of "New World Edentate," and "American Edentate." Here also, then, may be a starting point for Moore's poem about national origins, and in particular about remote likenesses between England and the New World's Old Dominion,Virginia. Moore's other edentate expert, Robert 
Moore, Pound, Syllabics, and History

Hatt, points out that African pangolins are rarely seen in American zoos because they do not survive well in captivity. He goes on: "The suggestion was once made that they might profitably be imported to the tropics of the New World to fight the destruction of fruit trees by leaf cutting ants" $(1934,732)$. Captive labor transported from Africa to cultivate the New World is also, of course, integral to the fabric of colonial Virginia, and troubling to the composition of "Virginia Britannia."

Marianne Moore and her mother spent the summers of 1934 and 1935 with her brother Warner, a navy chaplain recently returned from overseas and stationed for three years in Portsmouth, Virginia. All four poems in the Old Dominion sequence were composed during and between these visits, with "Jamestown," later called "Virginia Britannia," drafted in the summer of 1935. The previous year, the Moores had been among 30,000 tourists who visited Colonial Williamsburg to see work in progress on the restoration of the eighteenth-century town. Moore wrote to Bryher on August 27:

Last week we drove to Williamsburg to see the Rockefeller restorations - the Capitol and Governor's Palace. These colonial grandeurs and simplicities would not have excited you as much as they did us, but it was valuable and romantic in our eyes; the "strong sweet prison" with a shingle roof, and immense mulberry trees for colonial silk-worms, etc., in rebellious Yorktown! by way of which we came home. We had visited Warner in Yorktown in 1927 and had then gone to Williamsburg but some things keep on improving. Though if anyone could be inclined to think so, we are the ones to think that Yorktown was a mistake.

(SL 329)

In Moore's "some things keep on improving" there's a reminder that other things do not - that much has changed in the national landscape since 1927, and that the National Park Service's reconstructed earthworks and eighteenth-century buildings at Jamestown and Yorktown, like the philanthropically funded restoration of Colonial Williamsburg, took place against the background of the Depression. Luke Carson has written about Moore's civic republican view of "enforced idleness" $(2002,324)$ during the 1930s; in her poetic reconstruction of colonial history, "excellent idleness" ( $A-Q 18)$ is particular to the plantation South, and also, perhaps, a reflection on the privileged leisure time that she and her mother enjoyed as visiting tourists. 
Fiona Green

Moore's letter to Bryher makes light of their transatlantic difference: "colonial grandeurs" might not have been so impressive to an English heiress, and if by "Yorktown was a mistake" Moore pretends affectionately to regret the outcome of the revolutionary war, it could not have escaped her attention that the venue selected for the surrender of Cornwallis to Washington was the Moore House at Yorktown, which was restored and dedicated as a national monument in $1934 .{ }^{4}$ The "strong sweet prison" and the mulberry trees at Jamestown eventually find their way into "Virginia Britannia," and the hard work on the Old Dominion poems that Moore undertook between the two Virginia summers comes through meanwhile in a cryptic expletive invented for a letter to Warner. Perplexed by the task of revising her mockingbird poem, "Bird-Witted," she writes to her brother, "Ant-bears alive! Antbears at Williamsburg. Antbears of the Frye's Geography!" (SL 332). ${ }^{5}$ The antbear, or anteater, remote cousin to the pangolin, seems here to encode frustrating work on recalcitrant material and offers further evidence that "The Pangolin" belonged somehow, in Moore's mind, with the beginnings of the nation. Perhaps the most telling phrase in the letter to Bryher is that Williamsburg "was valuable and romantic in our eyes." As we shall see, work in progress on the Rockefeller restorations prompted Moore to think of a national narrative as a special kind of construction, and of the story of Virginia as a species of romance. ${ }^{6}$

In January 1935, the winter between her trips to Portsmouth, Moore received several letters from Ezra Pound haranguing her about economics. A typical example ends:

Work is not a commodity

Money is not a commodity

The STATE has credit. Just as I have credit at the Albergo

Rapallo. Can eat for three months without paying. I don't have to go to bank, borrow money, pay interest on it in order to lunch and dine

$$
\text { [hand-written] usury }
$$

when yew git that thaaaat last sentence/ you'll be a long way to understanding why hoover is a hog/ and the present administration just WEAK from the cervix upward.

These slogans are the persistent refrains of Pound's letters in the years following his brief audience with Mussolini (1933) and his 
Moore, Pound, Syllabics, and History

self-appointment to the role of court poet to Il Duce. He wrote dozens of letters like this to friends and associates and to public figures, promulgating social credit and fulminating against the banks. He circulated the lines beginning "Work is not a commodity" also in Social Credit: An Impact, his 1935 contribution to a series of pamphlets on the new economics published by Stanley Nott, the London publisher of C. H. Douglas. There's no mistaking the invective against usury, which increases in volume and viciousness in letters like this one, as also in Pound's poetry of the period, most notoriously in Canto 45, "With Usura. ..." (see Pound 1995, 229-30). The swipe against Hoover is more specific to the correspondence with Moore, whose support for the beleaguered former president has been well documented. ${ }^{7}$ By 1935 Pound has lost patience with "the present administration": despite Roosevelt's indictment in his 1933 inaugural of "the unscrupulous money changers" (quoted in Surette 1999, 143) the New Deal had, in Pound's view, failed because of its "idiotic accumulation of debt" (203) and Roosevelt's refusal to reform the banks. These are commonplaces, then, in Pound's correspondence, and they give a sense of the tone and idiom to which Moore was by now accustomed. Pound was, at the same time, keen to promote Moore's work, asking her several times to offer some critical prose to the New English Weekly. Moore suggested sending a poem, and Pound replied, in February 1935:

I don't know that I want a poem YET, unless you can do a new one, with econ/ consciousness sticking out of it (this izza matr of editn).

Also IF you ever go near a library / can you indicate any BUYABLE works (or worse, unbuyable ditto), throwin light on Financial stimulae of Jeff/Davis, and financing of the confederacy.

2. were there any abolitionist jews. (1935d)

Leon Surette has dated Pound's catastrophic turn from zealous economic reformer to anti-Semitic conspiracy theorist to just this moment, the winter of 1934 and the spring of 1935. Pound's increasingly paranoid understanding of American history, and especially of the causes of the Civil War, was fueled by his reading in Christopher Hollis's The Two Nations (1935) about the indebtedness of southern planters to northern banks, and by a bizarrely conspiratorial article "The Mystery of the Civil War and Lincoln's Death" by Silver Shirt founder William Dudley Pelley 
(see Surette 1999, 241.). These fictions, involving the manipulation of the abolitionist cause by finance capital, lie behind Pound's query to Moore about "abolitionist jews." He poses the same question to William Carlos Williams, to Louis Zukofsky, and most explicitly to Hugo Fack: "Have never been anti-semite, but things do pile up; is there any trace of jews in the abolitionist movement? I doubt. They were all over the south foreclosing mortgages after 1865. No jews in any ECON refo/ or monetary reform" (Pound 1996, 162). ${ }^{8}$ In 1935, Marianne Moore knew less than we do about what that question encodes and where it will lead (it was several years before she openly rebuked Pound for his anti-Semitism). ${ }^{9}$ She ignored it and replied instead to his other request: "If I go to Norfolk this summer, as I may, I shall write you regarding the Confederacy. There is a fine nest of southern politico-economic and colonial material in a small library across the river from Norfolk. My Brooklyn-Oxford surroundings do not yield much; though if anyone at Pratt library should 'push the bashful stranger to his food' your queries will not be deferred" (SL 342). Moore did return to Norfolk in the summer of 1935 , and it seems likely that she went to that small library across the river from Norfolk. She didn't, as far as I know, respond further to Pound regarding the Confederacy, but she may well have had his queries in mind when she was drafting her new poem, "Virginia Britannia." It's not a poem with economics sticking out of it, as Pound had wanted, but it is deeply attentive to the fabrication of history, and more conscious than its critics may have realized of the sometimes competing claims of region and nation in the romance narrative of the plantation South:

Pale sand edges England's old dominion. The air is soft, warm, hot, above the cedar-dotted emerald shore

known to the redbird, the redcoated musketeer, the trumpet-flower, the cavalier, the parson, and the wild parishioner. A deertrack in a church-floor brick and Sir George Yeardley's coffin-tacks and tomb remain. The now tremendous vine-encompassed hackberry 
Moore, Pound, Syllabics, and History

starred with the ivy-flower, shades the church tower.

And "a great sinner lyeth here" under the sycamore.

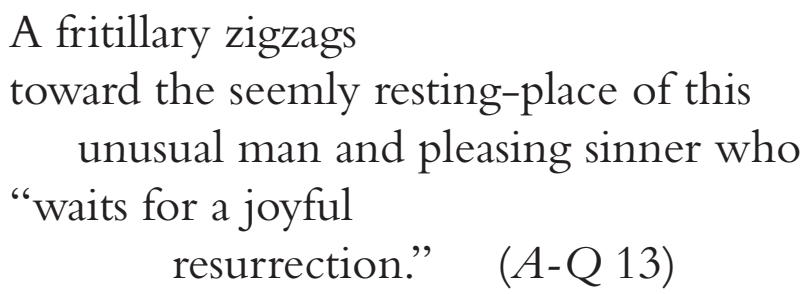

This is a richly legible space, littered with inscriptions, where you can track intimacies between words in their rearranged letters-as when "parson" persists in "parishioner"-and where newcomer might be mistaken for native, redcoat for redbird, because of their deceptive likeness. The line endings of Moore's syllabic stanzas contrive sometimes to rhyme-musketeer-cavalier-deer-while internal patterns also catch the ear to soften those edges of the verse: "cavalier" rhymes not just at the line end with "deer" but also internally with "Yeardley," much as the inner pathway near the left margin runs through track-brick-tack-hack and syc. There are more slender threads that look but don't sound like replications (from "redcoated" and "redbird" to "star-red" and "hamper-red"), and "ens" and "and"s seem to drop through the stanza from the first line's "sand" and "England," all these coincidences in the verse catching the restless, zigzagging attention that's cultivated by Moore's syllabics.

Critical responses to this lettered landscape have focused for the most part on the early colonial sources credited in Moore's published Notes to the poem (Travels and Works of Captain John Smith [1910] and William Strachey's History of Travaile into Virginia Britannia [1849]), and the first-encounter stories they narrate. But what's buried more deeply in the history of the poem's composition is the context in which Moore encountered those early texts, among the southern politico-economic material that she thought might be of particular interest to Pound. Her Reading Diary for 1930-43 includes notes most likely taken at the Hampton public library. ${ }^{10}$ References to Werewocomoco, to "Chick a conn," the Powhatan name for the Northern Neck of Virginia, and the phrase "on the Chickahominy," whose rhythmic contour survives in "Virginia Britannia," derive from pamphlets on the historic counties by W. H. T. Squires, Presbyterian minister and local historian whose 
sympathies may be discerned in his claim that after the Civil War, "The erstwhile slaves, who were exploited by venal politicians, became again happy and contented laborers" $(1935,7) .{ }^{11}$ Moore first came across Strachey's Historie of Travaile into Virginia Britannia in a footnote to the History of Hampton and Elizabeth City County Virginia, a book dedicated to "The Confederate Veterans of the Peninsula" by Lyon G. Tyler, prolific southern historian and author of Virginia First (1922), a pamphlet asserting the primacy of Jamestown over Plymouth as the point of national origin, and vocal proponent of Lee over Lincoln. "The land is fertile, sandy, alluvial and remarkably level," writes Tyler (1922, 9), and his history makes its way further into Moore's poem through its mulberry trees and silkworms. ${ }^{12}$

Moore's reading of the South took more immediate form too. Her Travel Notebook (1935-55) is packed with descriptions of sites such as the Jamestown churchyard she and her mother visited, its detail suggesting note-taking on the spot; but her response to these sites, and to the narrative of the Old Dominion, was also shaped by a tour guide: Virginia Highway Historical Markers: The Tourist Guide Book of Virginia Featuring the Inscriptions on the Official Markers along the Historic and Romantic Highways of the Mother State (1931). ${ }^{13}$ It begins, "The story of Virginia, however simply told, is one of romance" $(1931,13)$. According to this account, the history of "this romantic state and its more romantic people" has at its heart the cavalier myth which holds that "the first Virginians," including John Smith, the descendants of noble English houses, transplanted the Old World's feudal power structures in the New: "It came to be that a planter with his family and slaves, living on his vast estate, was like a feudal Baron; the very consciousness of his authority and his proprietary rights inevitably taught him to command, stirred his sense of independence, and ennobled his concepts of life and his manner of living." That sense of independence, fostered in the planter by his isolation, had its legacy in the revolutionary spirit of the eighteenth century: "They were aristocrats in England; they were aristocrats here. . . . The attachment to the mother country was everywhere in evidence; but there was brought out in this newer land everything that was essentially and gloriously Anglo Saxon-a planting that when domesticated in this land furnished the rebel that defied the stamp act" (105). This strongly end-directed narrative features in Moore's poem not just by way of "the trumpet-flower, the cavalier" at its start but also in this stanza: 
Moore, Pound, Syllabics, and History

show-mule \& witch-cross door \& "strong sweet prison" are part of what

has come about, in the Black

idiom, from advancing back-

ward in a circle;

from taking The Potomac

cowbirdlike; and on

The Chickahominy

establishing the Negro, opportunely brought, to strength-

en protest against

$$
\text { tyranny }(A-Q 16)
$$

Critical attention has focused on the 1941 version of these lines, where the negro serves as "inadvertent ally and / best enemy of / tyranny" ( $A G$ 42), the consensus being that he does so by the example of his own enslavement and eventual emancipation. ${ }^{14}$ But Moore's stanza makes better sense, especially in its earlier version, if it is read in line with the cavalier myth. According to that southern romance narrative, slavery "strength- / en $[\mathrm{s}]$ protest" against tyranny not because the slave protests his own freedom but because the feudal structure of which he is an integral part establishes the grounds of the Revolutionary War. Slavery in this view is foundational to the early republic, instrumental in securing the independence of the cavalier planter and, eventually, that of the nation.

"Virginia Britannia," then, may be more accommodating to a specifically southern historiography than has yet been allowed, so that the query for Moore, prompted in part by her correspondence with Pound, is over the integrity of a nation founded on a replicated feudalism and on the crime of chattel slavery. There is a complex layering, in the stanza last quoted, of copying and theft. The cuckoo-like cowbird, for example, hides its eggs in another bird's nest. If it is discovered, it will retaliate by destroying the host's progeny. To take territory "cowbirdlike" is to duplicate what is already a particularly nefarious form of imitation. Advancing backward in the stanza, we come to a still more curious instance of replication and criminality. In August 1935, Moore began recording black speech in her Travel Notebook:

Florence: (the fly) I losed him (nightgown) I leaved it on the grass

Nigger John:Well. Fla-ance I'll see you some moe 
Fiona Green

Florence. All right. Thank you, John

Mr. Duke: a colored man in court.

Witness: I saw him advancing backward in a circle with

a piece of scantlin' in his hand. (Moore 1935-55, 4v)

Whether the "piece of scantlin" was a makeshift weapon or the spoils of petty theft, "advancing backward" with it sounds like shady behavior. In this third- or fourth-hand report "in the Black / idiom"-the witness statement as recalled by $\mathrm{Mr}$ Duke, overheard and transcribed into Moore's Notebook and transferred to the poem-"Virginia Britannia" could be accused of making light of the crime at the heart of Virginia history, even of turning "advancing back- / ward in a circle" into a kind of burlesque. ${ }^{15}$ And if, as critics have sometimes suggested, "advancing backward" has something more serious to say about historical process, it's hard to know what it stands for. ${ }^{16}$ Does the plot of agrarian romance, by reviving Old World feudalism on the Chickahominy, provide the grounds for a forward-looking nation, or is it just a reactionary kind of nostalgia? These questions, and with them the ineradicable history of slavery and of tyranny in the plantation South, were made the more pressing for Moore by her correspondence with Ezra Pound.

While staying with her brother in the summer of 1935, Moore copied the following report from the local newspaper, the Virginian Pilot:

4 July 1935

Heavy Losses in Ethiopian Fight. Ethiopia to Concede Nothing to Mussolini, Haile Selassie Says. Emperor Signed Article Charging Italy with Arming Colonies and Provoking Trouble by Frontier Activities . ... "Concerning an Armed Italian Protectorate over Ethiopia, an old proverb says 'One shouldn't sell the lion's skin before killing the lion."'17

Why would an article about Mussolini have caught Moore's attention in the midst of her reading about colonial Virginia? My suggestion is that it's because Pound's Italy was on her mind, and, along with it, a query over the possibility of benign tyranny. Though the news recorded here from Ethiopia foregrounds resistance to Mussolini's colonial "adventure" in North Africa, it's worth remembering that Moore would write to Pound as late as November 1936 that she was reading his Jefferson and/or Mussolini (1935), which aligns Jeffersonian America with, as Pound saw it, Italy's benign dictatorship, "a page a day as a kind of 'daily light"” (SL 
Moore, Pound, Syllabics, and History

370). Could Moore have thought, albeit briefly, that the refinements of plantation life were the products, as she puts it toward the end of "Virginia Britannia," of "much // kind tyranny" (A-Q 18)? Might she have taken pleasure in the "excellent idleness / legitimate laziness" of southern romance, and the objects cultivated by its "tyrant taste"? Tempting though it is to resolve the difficulty of lines like these by assuming that they cannot mean what they say, or that they must be taken ironically, it seems to me that Moore was genuinely ambivalent, in 1935, about the possible kindnesses and comforts of agrarian economies. In its later version all mention of "kind tyranny" and "tyrant taste" has gone from the plantation scene in "Virginia Britannia," because there is no doubt, by 1941, about where European feudalism and empire building will lead-and no doubt either that Pound's continued support for Mussolini was a disastrous error of judgment. But in 1935, during the summer before the invasion of Ethiopia, and with Mussolini still enjoying a favorable image in the foreign press, Moore might very well not have thought unconscionable the alignment Pound wanted to propose, between Jeffersonian agrarianism and Mussolini's "Italy organic, composed of the last ploughman and the last girl in the olive-yards" (Pound 1935a, 34). ${ }^{18}$

If "Virginia Britannia" was in 1935 more accommodating to the cavalier myth than has previously been thought, Moore's fidgety reading of Virginia Highway also prompted a countermovement to the plot of southern historiography. The prefatory story in the book ("Westward the course of empire takes its way" [1931,13]) is followed by practical instructions on "How to Use" Virginia Highway: "You will enjoy reading the inscriptions from this book as you pass the hundreds of markers on your journey over the state" (21).The idea is that the tourist reads the guidebook as she drives the romantic highways of the mother state, matching the text on the page with signs on the road as her journey unfolds. What she will not find in this spatialized encounter with history is a sense of chronology. Instead, she zigzags across time, as, for example on a page from which Moore took some notes, in which the sequence of text dictated by the road map beneath it runs from seventeenth-century Governor Yeardley, through a British raid on the town of Suffolk in 1779, to the Confederate siege of Suffolk (1862), before switching back to William Byrd's survey of the Dismal Swamp in $1728 .{ }^{19}$ This spatial arrangement of time gives a more layered account of national and regional narratives than does the shapely cavalier plot. It is this overlaying of different historical moments in the same space that Moore registers in this passage: 
Fiona Green

The

rattlesnake soon

said from our once dashingly

undiffident first flag, "don't tread on

me," tactless symbol of a new republic.

Priorities were

cradled in this region not

noted for humility; spot

that has high-singing

frogs, cotton-mouth snakes and cot-

ton-fields; $(A-Q 17)$

Which story has priority in Virginia, Cradle of the Republic, as Lyon G. Tyler titled his book? Is it the rattlesnake, symbol of unity among the revolutionary colonies, or cottonmouth, the snake that bears in its name the product of a plantation economy whose coherence, in the end, would depend on resistance to Union? Is there a natural kinship, a line of descent that runs from cottonmouth to rattlesnake, or do they just happen to be found in the same place? It's hard to know in the version of this poem composed in 1935 where Moore's priorities and allegiances lie, but what we can say for certain is that linear narratives give way, in this kind of space, to a more contingent kind of historiography. What I'm also suggesting is that Moore is primed to think about US history in this way partly because of her experience of poetic composition, and of that syllabic environment in which like-sounding words nesting in the same spot might distract you into imagining some motivated connection or causal lineage - that an artist is cousin to an artichoke, a redcoat belongs with a redbird, or that a cottonmouth snake is so called because its habitat is a cotton field. ${ }^{20}$

Ezra Pound's reading of history and economics is quite different, in this respect, from Marianne Moore's. In the mid-1930s he was not detained by the verbal medium of the documents he read. This passage is from Pound's column in the New English Weekly, January 1935. He's writing as ever about social credit and about experiments with stamp scrip: "If an ex-engineer [C. H. Douglas], and ex-merchant of surgical implements [Silvio Gesell], in a given lustrum come on the same things that I, with certainly different preparation, am at the same time engaged in ramming into my cantos, there must be something or other THERE, 
Moore, Pound, Syllabics, and History

actual, sottostante, underneath the urge to get it set down, to get it onto paper, to get it expressed in words: a morale of the epoch" (Pound 1935b, 332). "Something or other THERE, actual, sotto-stante, underneath the urge to get it set down, to get it onto paper" insists on intrinsic likenesses that have nothing to do with words. ${ }^{21}$ In 1935, at more or less the same time that Moore was composing her Old Dominion and Pangolin poems, Pound was drafting his Fifth Decade, Cantos 42-51. He asked her about the financing of the Confederacy because he was thinking about agrarian economies, about autocratic forms of government, and about artisanal forms of labor. What he was urgently seeking, underneath it all, sotto-stante, was the kind of social organization that could resist the distortions of finance capital - the kind of economy that's immune to the degradations of usury. He found it in the Monte dei Paschi Bank of sixteenth-century Siena, in China, and in the early American republic. Underneath them all, in Pound's understanding, there is something THERE, something actual, and it is something like rhythm. This is from Jefferson and/or Mussolini:

The real life in regular verse is an irregular movement underlying. Jefferson thought the formal features of the American system would work, and they did work till the time of General Grant but the condition of their working was that inside them there should be a de facto government composed of sincere men willing the national good. When the men of understanding are too lazy to impart the results of their understanding. . . .I don't believe it matters a damn what legal forms or what administrative forms there are in a government. The nation will get the staggers. (Pound 1935a, 95)

What does this profoundly organicist alignment of versification and nation mean for poetic composition? How would the idea that there is some fundamental rhythmic coherence that underlies, as it were, the administrative surface of written language, work in practice? Canto 51, the last of the Fifth Decade, offers a particular angle on this question and brings us full circle if we remember that Moore's pangolin looks like a replica made from other things. Canto 51 sees Pound absorbed by the manufacture of fishing flies, artifacts intricately fashioned from the bodies of other creatures, and, like "The Pangolin" it also shows in detail a passage of verse made up from a body of prose, from Charles Bowlker's Art of Angling: 
Fiona Green

Blue Dun No 2

This fly is found on most rivers, and is in appearance one of the most delicate insects that frequent the water; and, what is rather extraordinary, it is more numerous, and the fish take it best, in dark cold weather. . . The wings . . . are to be made of a feather from a starling's wing, or a pale blue feather from under the wing of a duck widgeon ... . a fine blue cock's hackle for legs; the tail is forked, and is to be formed with two fibres from the same feather as the wings are made of; the hook No. 9. It may be used from ten o'clock in the morning till three in the afternoon; but the best time of the day is from twelve till two, particularly in March and April.

This is what Pound makes of Bowlker:

Blue dun; number 2 in most rivers for dark days when it is cold A starling's wing will give you the colour or duck widgeon, if you take feather from under the wing Let the body be of blue fox fur, or a water rat's or grey squirrel's. Take this with a portion of mohair and a cock's hackle for legs. $12^{\text {th }}$ of March to $2^{\text {nd }}$ of April

Pound draws verse out of prose by listening for the ghost of accentual meter, or by finding words and phrases tractable to his own deeply habitual rhythms. Bowlker's "Blue Dun No 2" shifts into "number two in most rivers;" "dark cold weather" Pound adjusts to "dark days when it is cold." He tampers with Bowlker even at the expense of conflating clock time and season: "The best time of day is from 12 til 2, particularly in March and April" Pound redrafts as "12th of March to second of April" because it makes rhythmic sense. ${ }^{22}$ Sometimes he will accept a phrase wholesale-as in "feather from under the wing"-because it gathers so readily into that instantly recognizable Poundian signature, reminiscent in cadence of the early cantos: "glitter of sun-rays," "sun-tawny sand stretch," "Pallor of Hesperus," "ply over ply" (1995, 3, 6, 10, 15)—these rhythms stabilize once again in " 2 on most rivers"; "when it is cold," "give you the colour." "That hath the light of the doer," says Pound, at the end of the fishing flies passage, "a form cleaving to it."

Readings of Canto 51 have differed in their views of Pound's likely attitude to the making of fishing flies. Robert Demott (1972), for example, 
Moore, Pound, Syllabics, and History

thinks that he admired its precision, care, and seasonality. David Moody, by contrast, thinks of the fishing fly as a dangerous forgery, the work of Geryon made from a heap of corpses (see Moody 2014, 233). Though I tend to concur with Demott's reading, as far as my account of rhythm is concerned, it doesn't matter whether Pound admires the manufacture of fishing flies or reviles it. It's not that rhythmic pattern is a marker, for him, of value-after all, the Usura Canto is one of the most rhythmically lovely of all. Still less do I want to claim that versification, be it syllabic as in Moore or accentual-syllabic as in Pound, is the outward code for an ideological position that is portable to other poets and other poems at other times. Rather than signs of this sort, these verse forms seem to me the symptoms of poetic consciousness, precipitations and provocations of their makers' ways of reading and thinking. It's intriguing to speculate about what Moore might have done with The Art of Angling. Perhaps she would have noticed forked and formed, starling and wing; where Pound listens to prose for echoes of his own rhythms, or reorganizes syntax to bring words into line with them, Moore might have glanced across from "fox" to "cocks" to "o'clock"; she would have been hooked at the surface of the writing, by the syllables and the letters that make them. Pound wants to "get it set down, to get it onto paper," and yet somehow also to bypass his own written medium, to put himself onto the page in all his rhythmic irregularity, and to have history reveal itself despite the accidents of its transmission. What I've been suggesting about Marianne Moore is that, because she counted syllables, she couldn't not see them — she couldn't see through or put aside what we might call the administrative surface of the prose she read or the stanzas she composed. The likenesses, patterns, and coincidences that catch the ear and eye in her syllabic verse do not reveal any deeper organic coherence, less still the lineaments of conspiracy. Likewise perhaps, for Marianne Moore, American history and even nations themselves are intricately bound up with the accidents of their transmission.<smiles>[CH]</smiles>

Fiona Green is senior lecturer in American literature at the University of Cambridge and a fellow of Jesus College. She has published widely on Moore and other American poets, in Critical Quarterly, Contemporary Literature, Symbiosis, Journal of American Studies, Genre, and TLS. Her edited collection Writing for the New Yorker appeared in 2015. 
Fiona Green

\section{Notes}

1. Abbreviations refer to these Moore texts: CPo, Complete Poems (1981); SL, Selected Letters (1997); BMM, Becoming Marianne Moore (2002); A-Q, A-Quiver with Significance (2008); and AG, Adversity and Grace (2012).

2. Moore refers to her "hybrid method of composition" in the "Note on the Notes" (CPo 262).

3. This suggestion is Benjamin Johnson's $(2007,139)$.

4. The restoration of the Moore House was completed, and the house formally dedicated, on October 18-19, 1934, the 153rd anniversary of Cornwallis's surrender to Washington and just two months after the Moores' visit to Yorktown.

5. The anteater appears in Frye's 1902 Complete Geography, 113.

6. White and Carson (2011) discuss in detail the treatment of literary romance and chivalry in Moore's 1932 poem "The Hero."

7. Carson (2002) discusses Hoover as the embodiment of civic virtue for Moore in 1932.

8. Pound asks the question of Williams in a letter of February 16, 1935 (see Pound 1996, 162). For the December 1934 letter to Hugo Fack, see Hugh Witemeyer's note to the same letter. For the May 1934 letter in which the question about abolitionist Jews is posed to Zukofsky, see Pound 1987, 157-60.

9. For the larger context of Moore's correspondence with Pound, see BarYaacov 1988. Bar-Yaacov discusses Moore's "silent disagreement with Pound over his attitudes towards the Jews" in 1933-34, focusing especially on his anti-Semitic jibes against Bryher: "It was not until 1939 . . that Moore finally referred openly to Pound's scurrilous attack" (520-22) on her close friend.

10. The Hampton Public Library, opened in 1926, fits Moore's description to Pound of a "small library across the river from Norfolk." Its catalogue includes copies of Smith 1910, Tyler 1922,Virginia Conservation 1931, and Virginia Navigation Co. 1897, the books from which Moore took notes in her Reading Diary 1930-43, printed dates September 1-18, 1923. Moore used old diaries for note-taking, in this case a diary from 1923. "Printed dates" are used in this and all subsequent references as page locators. They do not refer to the dates on which the notes were taken.

11. See Reading Diary 1930-43, printed dates August, 29-31 1923. 
Moore, Pound, Syllabics, and History

12. Moore's notes from Tyler appear in her Reading Diary 1930-43, printed dates September 11-13, 1923, the reference to Strachey on September 11, and that concerning the colonists' planting of mulberry trees and grapevines on September 12 (see Tyler 1922,16).

13. Moore's notes from Virginia Highway appear in her Reading Diary 1930-42, printed dates September 1-2, 1923.

14. Cristanne Miller, for example, writes, "Moore sees the seeds of tyranny's downfall in the slavery which embodied one of its worst exploitations of power: although 'inadvertent ally' in enslaved service, 'the negro' is also 'best enemy of / tyranny"” (1995, 152); for Bonnie Costello, "In their later resistance blacks are indeed 'inadvertent ally and best enemy of tyranny"' $(2003,113)$. Though my reading of these lines differs from hers, my larger argument does concur with Costello's claim that for Moore "history is not heroic narrative nor divine fiat but a set of contingencies" (107).

15. I am indebted to Stacy Hubbard for the suggestion, in conversation, that "advancing backward in a circle" might look like a cakewalk.

16. The most comprehensive reading of these lines, and of the larger conception of history in "Virginia Britannia," is still John Slatin's (1986). In Slatin's view, Moore attempts to rectify the "circular logic of American history" "by accept[ing] the very principles she is trying to correct" $(1986,246)$, especially those of imitation and appropriation. My argument differs most widely from Slatin's on the subject of syllabics. Whereas for Slatin Moore's verse form is essentially imitative (206), the suggestion of this article is that its lateral patterns disrupt linear historiography.

17. Reading Diary 1930-43, printed date August 26-27.

18. For the favorable foreign press that Mussolini enjoyed between the march on Rome (March 1922) and the Ethiopian war (October 1935), see Surette 1999, 72 .

19. Moore's notes from this page (Virginia Highway 159) appear in Reading Diary 1930-43, printed date September 1, 1923.

20. There are various possible derivations of the name "cotton mouth": cotton might be a corruption of the Greek name angkistrodon, from ancistro (hooked) and odon (tooth); or it may simply refer to the white interior of the snake's mouth. In neither case does it have to do with cotton fields.

21. The premise of Jefferson and/or Mussolini is likewise that "the fundamental likenesses between these two men are probably greater than their differences" 


\section{Fiona Green}

(Pound 1935a, 11). Pound goes on: "I am not diddling about with a paradox. The top dressing could hardly be more different, everything on the surface is different. The verbal manifestations or at least the more greatly advertised verbal manifestations undoubtedly differ to a very great degree."

22. These changes are visible in close-up in Pound's hand corrections to a typed draft of Canto 51, where he types "12 to 2, March and April," and revises in pencil to "12 of March" (Pound n.d.).

\section{Works cited}

Bar-Yaacov, Lois. 1988. “The Odd Couple:The Correspondence between Marianne Moore and Ezra Pound, 1918-1939.” Twentieth-Century Literature 34, no. 4: 507-27.

Bowlker, Charles. 1826. Art of Angling, Greatly Enlarged and Improved, Containing Directions for Fly-Fishing, Trolling, Bottom-Fishing, Making Artificial Flies Ec, Ec. Ludlow, UK: Proctor and Jones.

Carson, Luke. 2002. "Republicanism and Leisure in Marianne Moore's Depression." Modern Language Quarterly 63, no. 3: 315-42.

Costello, Bonnie. 2003. Shifting Ground: Reinventing Landscape in Modern American Poetry. Cambridge, MA: Harvard University Press.

Demott, Robert. 1972. "Ezra Pound and Charles Bowlker: Note on Canto LI." Paideuma 1, no. 2: 189-98.

Frye, Alexis Everett. 1902. Complete Geography. Boston: Ginn.

Green, Fiona. 2015. "Form in Modernist Poetry." A History of Modernist Poetry, edited by Alex Davis and Lee M. Jenkins, 23-35. Cambridge: Cambridge University Press.

Hatt, Robert T. 1934. "Pangolins: Certain Strange Anteaters of Africa and Asia." Natural History 34, no. 8: 725-32.

Johnson, Benjamin. 2007. "The Varieties of Aesthetic Experience in American Modernist Literature.” PhD Diss., Rutgers University.

Lydekker, Richard. 1894-95. The Royal Natural History. 6 vols. London: F. Warne.

Miller, Cristanne. 1995. Marianne Moore: Questions of Authority. Cambridge, MA: Harvard University Press.

Moody,A. David. 2014. Ezra Pound: Poet, a Portrait of the Man and His Work. Vol. 2. Oxford: Oxford University Press.

Moore, Marianne. 1930-43. Reading Diary. Rosenbach Library, Philadelphia, PA.VII:02:02.

1935-55. Travel Notebook. Rosenbach VII:04:10. 1981. The Complete Poems of Marianne Moore. Rev. ed. New York: Macmillan/Viking. 
Moore, Pound, Syllabics, and History

- 1986. The Complete Prose of Marianne Moore. Edited by Patricia C.

Willis. New York:Viking.

1991. Complete Poems. New York: Penguin.

1997. The Selected Letters of Marianne Moore. Edited by Bonnie

Costello, Celeste Goodridge, and Cristanne Miller. New York: Knopf.

- 2002. Becoming Marianne Moore: The Early Poems, 1907-1924. Edited

by Robin G. Schulze. Berkeley: University of California Press.

-2008. A-Quiver with Significance: Marianne Moore 1932-1936. Edited

by Heather Cass White.Victoria, BC: ELS.

-2012. Adversity and Grace: Marianne Moore 1936-1941. Edited by

Heather Cass White.Victoria, BC: ELS.

Morse, Frank Lincoln. 1923. Power, Its Application from the Seventeenth Dynasty to the Twentieth Century. Ithaca, NY: Morse Chain Company.

Pound, Ezra. n.d. Canto 51. Beinecke Rare Book and Manuscript Library.

YCAL MSS 43, series IV, box 74, folder 2611.

-1934. ABC of Reading. London: Faber.

1935a. Jefferson and/or Mussolini: l'Idea Statale Fascism as I Have Seen It.

London: Stanley Nott.

. 1935b. "Leaving Out Economics (Gesell as Reading Matter)." New English Weekly, January 31, 331-33.

1935c. Letter to Marianne Moore. January 22. TMS. AMS. Rosenbach $\mathrm{V}: 50: 07$.

1935d. Letter to Marianne Moore. February 18. TMS. Rosenbach $\mathrm{V}: 50: 07$.

1935e. Social Credit: An Impact. London: Stanley Nott.

1987. Pound/Zukofsky: Selected Letters of Ezra Pound and Louis Zukofsky.

Edited by Barry Ahearn. New York: New Directions.

1995. The Cantos. 13th printing. New York: New Directions.

1996. Pound/Williams: Selected Letters of Ezra Pound and William Carlos

Williams. Edited by Hugh Witemeyer. New York: New Directions.

Slatin, John. 1986. The Savage's Romance: The Poetry of Marianne Moore.

Philadelphia: Penn State University Press.

Smith, John. 1910. Travels and Works of Captain John Smith, President of Virginia and Admiral of New England 1580-1631. Edited by Edward Arber.

Introduction by A. G. Bradley. Edinburgh: John Grant.

Squires, W. H.T. 1935. Through Centuries Three: A Short History of the People of Virginia. Portsmouth,VA: Printcraft.

Strachey, William. 1849. The Historie of Travaile into Virginia Britannia: Expressing the Cosmographie and Comodities of the Country, Togither with the Manners and Customes of the People. Edited by R. H. Major. London: Hakluyt Society. 


\section{Fiona Green}

Surette, Leon. 1999. Pound in Purgatory: From Economic Radicalism to Anti-Semitism. Chicago: University of Chicago Press.

Tyler, Lyon G. 1922. History of Hampton and Elizabeth City County Virginia. Hampton,VA: Board and Supervisors of Elizabeth City County.

Virginia Conservation Commission. 1931. Virginia Highway Historical Markers:

The Tourist Guide Book of Virginia Featuring the Inscriptions on the Official Markers along the Historic and Romantic Highways of the Mother State. Strasburg,VA: Shenandoah.

Virginia Navigation Co. 1907. Afloat on the James. New York: Giles.

White, Heather Cass, and Luke Carson. 2011. "A Variety of Hero: Marianne Moore's Romance.” Journal of Modern Literature 34, no. 4: 63-83. 